\title{
Methodology of Determination of the Range of Restrictions Related to the Existence of Transmission Devices on Private Land-Case Study of Poland
}

\author{
Natalia Sajnóg ${ }^{1, *(\mathbb{C})}$, Katarzyna Sobolewska-Mikulska ${ }^{1}$ and Justyna Wójcik-Leń ${ }^{2}$ \\ 1 Faculty of Geodesy and Cartography, Department of Cadastre and Land Management, Warsaw University of \\ Technology, 00-661 Warsaw, Poland \\ 2 Department of Environmental Engineering and Geodesy, University of Life Sciences, 20-033 Lublin, Poland \\ * Correspondence: natalia.sajnog@pw.edu.pl
}

Received: 8 June 2019; Accepted: 8 July 2019; Published: 10 July 2019

check for updates

\begin{abstract}
Transmission devices constitute a fundamental need. Moreover, the facilities introduce numerous restrictions on land, beginning with their actual permanent physical existence, through bans on construction and planting trees, to the possibility that the land is used by transmission companies (easement). In Poland, no legal provisions or coherent and uniform rules at the national level currently exist that would determine the range of execution of the easement right. This is confirmed by research performed by the authors. The first analysis covered legal acts as well as norms and technical guidelines for particular types of transmission infrastructure. The second study analysed was a survey conducted on a group of transmission companies representing different industries. The third study (supplementing the previous ones) concerned the analysis of two case studies in the scope of the discussed issue. The objective of this article was to develop a methodology for the determination of the scope of the easement right resulting from the existence of transmission devices on private land in Poland. The developed concept showed that the range should depend in particular on the type of land use in question. The model procedure proposed by the authors was developed in reference to environmental, social, and economic aspects, in accordance with the assumptions of sustainable land management.
\end{abstract}

Keywords: land use; range of restrictions; sustainable land management; transmission devices; easement; real estate rights

\section{Introduction}

Technical infrastructure is defined as a group of basic objects, facilities, and installations such as roads, bridges, power and telecommunication lines, pipelines for transmission of water, sewage, petroleum products, and other facilities with a service character [1]. Its characteristic feature is its course through a great deal of private land characterised by different protection statuses, e.g., arable land, forest land, Natura 2000 areas, landscape parks, urbanised areas, and land with increased flood risk. It should be emphasised that the effect of technical infrastructure is particularly strong in reference to agricultural space [2,3]. The infrastructure also largely affects rural landscape which has been changing quite slowly, though constantly. According to Hernik, Gawroński and Dixon-Gough [4], the landscape is most diverse in rural areas. Among other things, this contributes to urban sprawl, promotion of building development in local spatial plans, and the building of new infrastructure (i.e., roads and highways, transmission devices, etc.) [5]. Finally, it should be noted that landscape and space are significant non-renewable resources which need to be managed rationally, according to the rules of sustainable development [6]. 
The concept of sustainable development appeared for the first time in 1987 in the so-called Brundtland Report of the UN World Commission on Environment and Development, in which economic and ecological objectives are related to social objectives, and therefore to just division of natural resources. Later, the idea of sustainable development was rather broadly popularized at the Earth Summit in Rio de Janeiro in 1992. From that moment, the term became popular in the ecological awareness, and was adopted in politics and discussions of economics [7]. "Transforming our world: the 2030 Agenda for Sustainable Development" [8], adopted in 2015 by 193 states of the United Nations Organisation, is an action programme with an unprecedented scope and importance, defining the model of sustainable development at the global level. Agenda 2030 is of universal, horizontal character, and is very ambitious. It covers 17 Sustainable Development Goals and 169 targets. The responsibility for its implementation lies with the entire international community: developed countries, developing countries, and international organisations they are members of. One of the 17 goals of the Agenda is to "Build resilient infrastructure, promote inclusive and sustainable industrialisation and foster innovation", which in the scope of the analysed issue is related to a specific target, defined as follows: "Develop quality, reliable, sustainable and resilient infrastructure, including regional and transborder infrastructure, to support economic development and human well-being, with a focus on affordable and equitable access for all".

Sustainable development is a major concern of various social-economic systems throughout the world. As a critical component of sustainable development, infrastructure should be designed and implemented to make positive contributions to the economic, environmental, and social sustainability of the supported regions and communities. The issue of sustainable development of transport, and the reduction of its impact on climate change, human health, and biological diversity, has been a subject of deep concern for years [9-12]. It particularly involves the application of spatial modelling tools, such as geographical information systems and decision support systems [13,14], and in the scope of land consolidation works in rural areas [15]. Appropriate activities are also undertaken in the scope of sustainable development, as well as energy engineering and water management. Energy savings and promotion of renewable energy sources are an essential part of the energy policy [16-20], aimed at ensuring competitiveness, sustainability, and security of energy supply, as well as their integration with the best environmental practices to reduce emissions of $\mathrm{CO}_{2}$ and other greenhouse gases [21-24]. Moreover, the primary challenge is currently to ensure public health and to satisfy water needs while preserving the quality and quantity of water resources for future generations through efficient production and use of water [25]. This gains particular importance in the current period of climatic changes $[26,27]$. Transportation, water supply, and energy-related assets, including transmission lines, are part of the so-called "critical infrastructures" in that they provide essential services for the economy and functioning of society. All procedures related to their development should therefore constitute conscious and planned effort, corresponding with environmental sustainability visions, and be reflected in rational spatial planning [21,28-30] and sustainable land management [31,32]. They should permit the use of land resources for economic and social purposes, simultaneously protecting the long-term productive potential of such resources, and ensuring the maintenance of their environmental functions. Due to the specificity of the article, the above issue will be limited to transmission infrastructure.

Transmission-related investments introducing permanent spatial and landscape changes often meet with opposition from local communities. Their negative attitude results from economic and sentimental losses. Economic losses (compensated for with a financial equivalent) include: (1) losses in useful land, (2) change of land use or purpose (e.g., ban on construction), (3) restrictions in the use of land (e.g., ban on planting trees), (4) permanent existence of facilities on private land [33-35], and (5) landscape losses [36-38]. Sentimental losses are related to the individual perception of landscape defined as influencing the general feeling of wellbeing [39-41], and "sense of place" is understood as a cultural ecosystem service and multi-dimensional concept involving emotional attachment, satisfaction, and identity [42-44]. Finally, it should be noted that transmission devices negatively affect the spatial 
conditions of private lands, limit the possibility of its efficient management [45], decrease environmental and landscape values [3,38], and as a consequence reduce the value of the property $[46,47]$.

No legal instruments currently exist in Poland that would afford land owners permanent protection of their land against future investments. Such policies are applied, for example, in North America, through the establishment of conservation easement, which is a market-based tool used to protect environmental amenities and ecosystem services that arise on private land [48]. Conservation easement may also be used to buffer agricultural land from encroaching on residential or industrial land uses [49-51].

"Tools" exist, however, in the form of relevant legal titles that enable companies to implement a transmission investment even if the property owner does not express relevant consent. The basic title of this type in Poland is currently transmission easement. This right guarantees a company permanent legal title to land, i.e., it provides the possibility of implementing an investment as well as later existence of the infrastructure in the space of the land property. It imposes the obligation on the property owner to comply with a number of restrictions.

Therefore, the range of the restrictions should not be incidental, but should result from the assumptions of sustainable land management which combines technologies, policies, and activities aimed at integrating socio-economic principles with environmental concerns so as to simultaneously maintain or enhance production, reduce the level of production risk, protect the potential of natural resources and prevent (buffer against) soil and water degradation, be economically viable and socially acceptable, and assure community access to the benefits from improved land management [31]. Therefore, the in view of current challenges, rational land management that, in the analysed case concerns appropriate determination of the range of restrictions on land under various uses, is of key importance.

In this article, the authors undertake a discussion on the rules of determining the ranges of transmission easements established by companies in Poland. For this purpose, the study involved: (1) the analysis of legal acts, norms, and technical guidelines for particular types of transmission infrastructure in search of provisions that would define ranges of established easements; (2) a survey among companies representing different branches for the purpose of obtaining answers concerning the dimensions of the established ranges and rules of their determination; and (3) the analysis of two case studies in the scope of the analysed subject. Based on the obtained results, the authors developed a methodology of determination of the range of restrictions resulting from established transmission easements in Poland, tested on a model object.

\section{Selected International Solutions in the Scope of Restrictions Resulting from the Existence of Transmission Devices on Private Land}

Easement is a commonly known legal title permitting the development of many areas of the economy. Easements are the oldest form of property rights over the property of others, dating back to Roman times when the climate and land relief forced the use of a neighbour's land for the efficient management of one's own [52]. Roman law designated easements of rural and urban land and personal easements. The former constituted the prototype of the legal title related to the construction of transmission devices currently obtained by transmission companies: water-pipe law, i.e., the right of transmitting drinking water through other people's land [52,53].

Under feudalism, the system of servitude was greatly extended beyond its origin in Roman law. This can be seen as part of a general trend under feudal law whereby the notion of absolute ownership underwent a substantial change [54]. The legacy has been accepted with no reservations by scientific and European legislatures until today [55].

Due to different historical, social, and economic conditions, the specificity of legal regulations and technical solutions related to the registration of rights to land differs from country to country [56]. A different specificity also concerns legal titles obtained by transmission companies and rules of determination of ranges of restrictions caused by transmission devices. The characteristics of selected international solutions are presented below. 


\subsection{Canadian Solutions}

In Canada, which has a federal system of government, the responsibility for land law results from legal regulations of particular provinces [57]. For example, in Ontario, easement can be established based on a civil law act. Registration of the document at the Local Registry Office is obligatory. It is also possible to establish easement through prescriptive rights. The establishment of easement requires the preparation of a reference plan presenting the proposed boundaries of the future or existing transmission corridors. In the case of public purpose investments and a lack of consent from the owners of private land, obtaining rights to land occurs based on the expropriation of the required width of the land belt. Owners of the land property are entitled to financial compensation for the established legal titles. The widths of the transmission easement belts are not legally imposed. Transmission companies have their own guidelines, although local governments recommend their respective widths in their design standards.

\subsection{Latvian Solutions}

In Latvia, the implementation of infrastructural investments involving the construction of transmission devices primarily occurs based on civil law agreements: (1) rights to construct an object, (2) leasehold, and (3) easement [58]. If the land owner does not wish to enter into an agreement, the relevant legal title to the land is established based on a court ruling. Agreements are subject to registration in the Legal Register (Landbook). In the case of on-ground volume objects (e.g., electrical substations), expropriation of land is performed. The range of spatial restrictions related to the functioning transmission infrastructure is defined by legal provisions [59]. Particular types of transmission devices depending on technical parameters are ascribed respective protection zones. For example, for overhead power lines, a land area and airspace at the height of this line, delimited by notional vertical planes on both sides from the outer wire of the overhead lines of electric power networks with a nominal voltage above $110 \mathrm{kV}$, is $30 \mathrm{~m}$. In populated areas this corresponds to $8 \mathrm{~m}$.

\subsection{Slovakian Solutions}

In Slovakia, the basic legal titles obtained by transmission companies in relation to the implementation of infrastructure investments are easements. Easements can be established based on a civil law agreement, court ruling, or administrative decision [60-62]. In the case of electric power devices, they can also be established based on binding law [63]. In such a situation, the easement arises on the day when the transmission company obtains a license for operation or acquires a building permit. The license holder shall be obliged to notify the property owner in writing of the registration of an easement in cadastre [64]. The transmission entrepreneur shall pay to the property owner a reasonable one-off indemnity for the establishment of easement and for the limited use of land corresponding to the level of restriction of a common use of the property. The scope of the range of easements is almost always defined by law. Almost every type of transmission device is regulated through a dedicated legal standard. For example, for overhead power lines with a voltage from 110 to $220 \mathrm{kV}$, the range of execution of easement reaches a distance of $20 \mathrm{~m}$ from the outer wires of the line. Apart from the legally defined size of the servient tenement, transmission companies define specific rules of protection (such as the prohibition to plant and grow permanent crops, plant trees, build buildings and fences, dig wells, etc.). When the scope of the rights is not defined by law, the limitation is only in the range of the actual position of the transmission device (without other spatial restrictions and compensation).

\subsection{Bulgarian Solutions}

In Bulgaria, the implementation of transmission investments on private land is based on the established land easement. Legal provisions strictly define the method of establishment and range of easement [65-67]. The right to pass deviations from common networks and facilities of the technical infrastructure through foreign real estate is established by a written agreement between the owners of the land with a notary certification of the signatures. Where no consent can be obtained between 
the land owners, and no other technical solution is clearly economically appropriate, the easement right shall be established by order of the mayor of the municipality or regional governor. In reference to water supply pipelines, a right on land easement can be also acquired by prescription in the case of a 10-year period of continuous use. The established easements should be registered in the Land Register (Cadastre) and Property Register. Indemnifications are payable due to the established right in the scope stipulated by legal provisions. The estimation is based on market data. Legal provisions also regulate the issue of ranges of the established easements. For example, for overhead power lines with a voltage of $110 \mathrm{kV}$ or $220 \mathrm{kV}$, in populated areas their range reaches a respective distance of $4 \mathrm{~m}$ and $6 \mathrm{~m}$ from the maximum reach of the outer wires of the line. For agricultural areas, it is $3 \mathrm{~m}$ from the maximum reach of the outer wires of the line irrespective of the line's voltage.

\subsection{Belarusian Solutions}

In the Republic of Belarus, $98 \%$ of the land area is currently in state ownership. Therefore, problems with the establishment of easements on private land properties arise very rarely. Developer processes in Belarus include the construction design, its examination, obtaining construction licenses, etc. As a rule, designs for the construction of engineering networks and connections to them are usually carried out using state land. However, if the land constitutes private property, the right of use of the area is carried out on conditions determined by an easement contract or by a court decision. The contract of an easement and the right of an easement are subject to state registration. The scope of easement and conditions of use of the land are defined by technical regulations or by the contract.

\subsection{Ukrainian Solutions}

In Ukraine, since 2007, the implementation of infrastructural investments involving the construction of transmission devices can occur based on the established easements (land easements). They can arise based on an agreement, court ruling, or binding law [68]. The preferred statutory tool is the civil law agreement. The establishment of the said right is generally subject to fees (i.e., a fee for the joint use of the real estate). Moreover, the indemnification can cover compensation for losses resulting from lost benefits. In such a situation, however, it has to strictly result from the document establishing the easement. The resulting right should be registered in the land and mortgage register. The scope of execution of the easement should always be specified. The rules of determination of the range of the established easements are also not regulated by law. Exclusively in reference to electric power lines, they indirectly depend on technical guidelines, which, however, do not constitute legal provisions.

\section{Methods}

For the purpose of developing the methodology of determination of the scope of restrictions related to the existence of transmission devices on private land (the scope of transmission easement) in Poland, with consideration of sustainable land management, the following was performed: (1) analysis of the content of legal acts, norms, and technical guidelines in search for provisions that would define ranges of established easements; (2) a survey for the purpose of obtaining answers concerning dimensions of the ranges of easements established by companies, and rules of their determination; and (3) analysis of case studies in terms of the analysed issue.

\subsection{Analysis of the Content of Legal Acts, Norms, and Technical Guidelines}

Legal acts, norms, and technical guidelines were analysed in search for provisions that would define ranges of established easements or could define rules of their determination. The research was conducted in reference to the following main types of transmission devices: (a) overhead power lines; (b) gas pipelines; (c) oil pipelines; (d) power and signalling cable lines; (e) telecommunication lines; (f) water supply pipelines; (g) sewage pipelines; and (h) heating pipelines. 


\subsection{Survey}

The survey on the dimensions of ranges of established easements and rules of their determination was conducted among transmission companies. Questionnaires were sent to 130 companies representing different branches of transmission infrastructure in Poland. The list of respondents was prepared based on company registers available in the Bulletin of Public Information. The questionnaires were directed to representatives of management boards (presidents) of particular companies. After prior consultations and internships conducted at companies, knowledge was obtained that the determined ranges constitute an arranged unified position of a given company.

The questionnaire asked about the range of the established easements depending on: (1) the type of transmission device; (2) technical parameters of the device; (3) other factors, including, e.g., (a) location towards the land surface, (b) land use (or land management), (c) surface area necessary for the performance of operation works, (d) surface area necessary for eliminating failures, and (e) other factors, if they affect the range of the established easements. Care was taken for the catalogue of parameters specified in the question to be of disobliging and open character. No answers were suggested. Therefore, the questionnaire additionally included a request for the explanation of rules of determination of the specified range.

\subsection{Case Studies}

Analyses of spatial restrictions occurring in the scope of the established easements were also performed based on the example of two objects.

The first with strategic importance at the national level was the double track $400 \mathrm{kV}$ Ełk-Polish border power line, the so-called "Poland-Lithuania power line connection". The study covered a section of the line with a length of approximately $21 \mathrm{~km}$ located in north-eastern Poland in the Warmińsko-Mazurskie voivodship, within the administrative boundaries of the Wieliczka (154 cadastral parcels) and Olecko (55 cadastral parcels) communes. The line runs through land with variable land use and land management.

The second was an investment with supralocal character: a $15 \mathrm{kV}$ cable power line feeding the power lines of the Polish Railways with a length of approximately $1.5 \mathrm{~km}$, also located in the Warmińsko-Mazurskie Voivodship, in the Rybno commune, Tuczki village (16 cadastral parcels). The line runs through agricultural land with admitted homestead building development.

\section{Results}

\subsection{Results of Analyses of the Content of Legal Acts, Norms, and Technical Guidelines}

In the Polish legal system, a hierarchical system of law sources is binding. At the top, right after the Constitution of the Republic of Poland, there are legal acts and legal regulations that should be absolutely respected. The application of Polish norms is voluntary [69]. Technical guidelines are also only recommended for application. Considering the aforementioned importance and restrictiveness of application of the above regulations, a list of the main legal acts, norms, and technical guidelines was prepared that refer to the analysed types of transmission infrastructure devices (Table 1).

Table 1. Systematics of legal acts, norms, and technical guidelines referring to transmission infrastructure devices.

\begin{tabular}{lllll}
\hline No. & Type of Transmission Device & $\begin{array}{l}\text { Type and Name of } \\
\text { Regulation }\end{array}$ & $\begin{array}{l}\text { Short Description of the Regulation in } \\
\text { the Scope of the Analysed Issue }\end{array}$ & $\begin{array}{l}\text { Range of } \\
\text { Easement }\end{array}$ \\
\hline 1. & All transmission devices & $\begin{array}{l}\text { Act [70] } \\
\text { Act [71] }\end{array}$ & $\begin{array}{l}\text { Definition of transmission easement } \\
\text { Definition of transmission devices }\end{array}$ & not applicable/lack \\
\hline 2. All transmission devices & Act [72] & $\begin{array}{l}\text { Decision restricting the way of use of land } \\
\text { property -Alternative legal title for } \\
\text { transmission easement (only in the case of } \\
\text { implementation of a public purpose) }\end{array}$ & not applicable/lack \\
\hline
\end{tabular}


Table 1. Cont.

\begin{tabular}{|c|c|c|c|c|}
\hline No. & Type of Transmission Device & $\begin{array}{l}\text { Type and Name of } \\
\text { Regulation }\end{array}$ & $\begin{array}{l}\text { Short Description of the Regulation in } \\
\text { the Scope of the Analysed Issue }\end{array}$ & $\begin{array}{l}\text { Range of } \\
\text { Easement }\end{array}$ \\
\hline 3. & All transmission devices & Act [73] & $\begin{array}{l}\text { Rules and courses of procedure in the scope } \\
\text { of environmental impact assessments of the } \\
\text { undertaking, description of the rules of } \\
\text { society's participation in } \\
\text { environmental protection. }\end{array}$ & not applicable/lack \\
\hline 4. & All transmission devices & Act [74] & $\begin{array}{l}\text { Rules of environmental protection in the } \\
\text { implementation of the investment. } \\
\text { Restrictions in the way of use of land } \\
\text { property due to environmental protection }\end{array}$ & not applicable/lack \\
\hline 5. & Overhead power lines & Regulation [75] & $\begin{array}{l}\text { Admissible levels of electromagnetic fields } \\
\text { in the environment depending on land use }\end{array}$ & not applicable/lack \\
\hline 6. & Overhead power lines & Regulation [76] & $\begin{array}{l}\text { Admissible noise levels in the environment } \\
\text { depending on land use }\end{array}$ & not applicable/lack \\
\hline 7. & Gas pipelines & Regulation [77] & $\begin{array}{l}\text { Rules of designing, construction, and } \\
\text { alteration of gas pipes }\end{array}$ & not applicable/lack \\
\hline 8. & Oil pipelines & Regulation [78] & $\begin{array}{l}\text { Rules of construction and alteration of } \\
\text { oil pipelines }\end{array}$ & not applicable/lack \\
\hline 9. & Telecommunication lines & Regulation [79] & $\begin{array}{l}\text { Rules of designing and construction of } \\
\text { telecommunication lines }\end{array}$ & not applicable/lack \\
\hline 10. & Overhead power lines & Norm [80] & $\begin{array}{l}\text { Rules of designing and construction of } \\
\text { overhead power lines }\end{array}$ & not applicable/lack \\
\hline 11. & Overhead power lines & Norm [81] & $\begin{array}{l}\text { Rules of designing and construction of } \\
\text { overhead power lines }\end{array}$ & not applicable/lack \\
\hline 12. & Overhead power lines & Norm [82] & $\begin{array}{l}\text { Rules of designing and construction of } \\
\text { overhead power lines }\end{array}$ & not applicable/lack \\
\hline 13. & Overhead power lines & Norm [83] & $\begin{array}{l}\text { Rules of designing and construction of } \\
\text { overhead power lines }\end{array}$ & not applicable/lack \\
\hline 14. & $\begin{array}{l}\text { Power and signalling } \\
\text { cable lines }\end{array}$ & Norm [84] & $\begin{array}{l}\text { Rules of designing and construction of } \\
\text { power and signalling cable lines }\end{array}$ & not applicable/lack \\
\hline 15. & Water supply pipelines & Guidelines [85] & $\begin{array}{l}\text { Rules of designing a construction of water } \\
\text { supply pipelines }\end{array}$ & not applicable/lack \\
\hline 16. & Sewage pipelines & Guidelines [86] & $\begin{array}{l}\text { Rules of designing and construction of } \\
\text { sewage pipelines }\end{array}$ & not applicable/lack \\
\hline 17. & Heating pipelines & Guidelines [87] & $\begin{array}{l}\text { Rules of designing and construction of } \\
\text { heating pipelines }\end{array}$ & not applicable/lack \\
\hline
\end{tabular}

In Poland, since 2008, in addition to land and personal easements, transmission easement is also designated $[53,88,89]$. According to the statutory definition, the right enables the company to use the encumbered property in the specified scope in accordance with the purpose of the devices [70,71]. The introduced title is dedicated exclusively to investments with an industrial character. Until the time of its introduction, this type of undertaking could be implemented based on right of use, land easement, or contract law (i.e., rental, leasing, lending). In reference to public purpose investments, and in the case of a lack of consent of the land owner, they could also be implemented based on an administrative decision restricting the use of the real estate [72]. The decisions can also be issued currently but they do not establish transmission easement. However, they entitle transmission companies to use the land of others with a limited scope.

The preferred way in Poland to obtain rights to land for both the time of construction of a transmission device and its operation is currently via a transmission easement. The said limited property right can be established based on a civil law agreement, court decision, or by prescriptive rights. The objective of the introduction of the new regulation was to provide transmission companies with permanent legal title to land. Moreover, the provision aimed at guaranteeing access to transmission devices already constructed on the property of others-so-called "regulation of past circumstances", i.e., when the devices were constructed in the past without the transmission companies having a legal title to private land.

The established transmission easement is the basis for applying for a decision on a building permit. In the case of investments with high technical parameters, the decision is preceded by the preparation 
of an environmental impact assessment (EIA) [73]. An EIA considers the impact of an investment on the health and living conditions of people, material goods, historical sites, and the availability of minerals. An EIA therefore refers to the range of effects of different restrictions to which national legal acts, norms, and technical guidelines are applicable (Table 1).

The provisions of the act [74] are particularly important to the above mentioned issue. According to them, "Exploitation of the installation causing the introduction of gases or dusts to the air, noise emission, and generation of electromagnetic fields should not cause exceedance of environmental quality standards outside the area to which the entity providing the installation has legal title. An exception is a situation when an area of limited use was established for the device. Then, the operation of the installation should not cause the exceedance of standards of environmental quality outside such an area".

An area of limited use is defined as a legally determined area under the effect of a plant or another object, for example, a wastewater treatment plant, municipal waste dump, composting plant, transportation route, airport, power line and station, or radio communication, radio navigation, or radio location installation. Therefore, if the area of limited use was not established, exceedance of environmental quality standards cannot exceed the area to which the company has legal title. The area cannot exceed the range of the established transmission easement.

Regulations defining admissible values of environmental impact of transmission devices are regulations [75,76] concerning respectively admissible levels of electromagnetic fields and admissible noise levels. The former particularly refers to overhead power lines.

Table 2 presents the physical parameters characterising the effect of electromagnetic fields on the environment and their acceptable levels, respectively, for areas designated for residential building development and areas accessible to the public.

Table 2. Acceptable levels of physical parameters characterising electromagnetic field frequencies of electrical networks depending on the purpose of the land [75].

\begin{tabular}{lllll}
\hline No. & Type of Land & $\begin{array}{l}\text { Range of Frequencies of } \\
\text { Electromagnetic Field }\end{array}$ & $\begin{array}{l}\text { Electric } \\
\text { Component }\end{array}$ & $\begin{array}{l}\text { Magnetic } \\
\text { Component }\end{array}$ \\
\hline 1 & $\begin{array}{l}\text { Designated for residential building } \\
\text { development }\end{array}$ & $50 \mathrm{~Hz}$ & $1 \mathrm{kV} / \mathrm{m}$ & $60 \mathrm{~A} / \mathrm{m}$ \\
\hline 2 & $\begin{array}{l}\text { Accessible to the public } \\
\text { (e.g., agricultural areas, forest areas) }\end{array}$ & $\leq 0.5 \mathrm{~Hz}-50 \mathrm{~Hz} \geq$ & $10 \mathrm{kV} / \mathrm{m}$ & $60 \mathrm{~A} / \mathrm{m}$ \\
\hline
\end{tabular}

According to the above table, the threshold value of the amperage of the magnetic component of the electromagnetic field for both areas accessible to people and those designated for residential building development equals $60 \mathrm{~A} / \mathrm{m}$ for frequencies of electrical networks amounting to $50 \mathrm{~Hz}$ (maximum frequency of power line). Differences occur in the threshold levels of the electric component that should not exceed $1 \mathrm{kV} / \mathrm{m}$ for areas designated for residential building development nor $10 \mathrm{kV} / \mathrm{m}$ for places accessible to the public (e.g., agricultural areas, forest areas).

According to regulation [76], the acceptable level of noise is only subject to the norm for built-up areas. Legal provisions do not regulate the threshold values of noise levels for agricultural and forested areas. The acceptable values of indicators LDWN (day-evening-night level) and LN (long-term level) that are applicable for conducting a long-term policy in the scope of protecting against noise from overhead electrical transmission lines are presented in Table 3. 
Table 3. Acceptable levels of long-term medium level of noise expressed in LDWN (day-evening-night level) and LN (long-term-night level) indicators [76].

\begin{tabular}{llll}
\hline No. $\quad$ Type of Land & \multicolumn{2}{c}{ Acceptable Long-Term Medium Level of Noise [dB] } \\
\cline { 3 - 3 } & $\begin{array}{l}\text { LDWN Reference Period } \\
\text { Equal to all Days in a Year }\end{array}$ & $\begin{array}{c}\text { LN Reference Period Equal } \\
\text { to all Times at Night }\end{array}$ \\
\hline $\begin{array}{l}\text { 1. } \quad \begin{array}{l}\text { Protection zone "A" health resorts; premises of hospitals, } \\
\text { public nursing homes; areas of building development related } \\
\text { to permanent or temporary stays of children and youth. }\end{array} \\
\text { to }\end{array}$ & 45 \\
\hline $\begin{array}{l}\text { Areas of single- and multi-family homesteads and collective } \\
\text { residency development; recreational areas; residential and } \\
\text { service areas; areas in centres of cities with a population of } \\
\text { more than } 100 \text { thousand. }\end{array}$ & 50 & 45 \\
\hline
\end{tabular}

The remaining regulations [77-79], norms [80-84], and technical guidelines [85-87] specified in Table 1 are applicable in the design, construction, and alteration of transmission devices. They provide minimum distances from other devices and buildings. Their content, however, does not refer to the environmental impact of the device defined in the environmental and social sense, except for provisions concerning clearing trees.

Importantly, then, none of the regulations presented in Table 1 specifies ranges of established transmission easements, or rules of their determination.

\subsection{Survey Results}

Out of the 130 questionnaires sent, 34 responses were obtained. The response rate (26\%) proved to be somewhat below expectations [90]. The analysis of the answers provided showed a relatively high reluctance of transmission companies to provide information on the established easements and resulting restrictions. Moreover, $32 \%$ of the obtained responses constituted a refusal to provide any information, which was justified by "trade secrets'" Further follow-up administering the survey might have increased the response rate. However, it was decided that cooperation with transmission companies and their anonymity would be better preserved if no further follow-up occurred, even if the overall response rate was low.

Tables 4-7 include the obtained results. The presented results do not cover telecommunication lines, oil pipelines, sewage pipelines, and heating pipelines, because for those devices, the sent answers did not permit a pair comparison. The ranges specified in the tables constitute a range of space with the middle on the axis of the transmission device projected on the xy-plane.

Table 4. Range of spatial restrictions determined by electricity transmission companies depending on the voltage of overhead power lines.

\begin{tabular}{|c|c|c|c|c|c|c|c|c|}
\hline \multicolumn{9}{|c|}{ A1 } \\
\hline & $400 \mathrm{kV}$ & $220 \mathrm{kV}$ & $110 \mathrm{kV}$ & $20 \mathrm{kV}$ & $15 \mathrm{kV}$ & $6 \mathrm{kV}$ & $3 \mathrm{kV}$ & $<1 \mathrm{kV}$ \\
\hline $\begin{array}{l}\text { Range of spatial restriction } \\
\text { (transmission easement) [m] }\end{array}$ & 70.0 & 50.0 & - & - & - & - & - & - \\
\hline \multicolumn{9}{|c|}{ B1 } \\
\hline & $400 \mathrm{kV}$ & $220 \mathrm{kV}$ & $110 \mathrm{kV}$ & $20 \mathrm{kV}$ & $15 \mathrm{kV}$ & $6 \mathrm{kV}$ & $3 \mathrm{kV}$ & $<1 \mathrm{kV}$ \\
\hline $\begin{array}{l}\text { Range of spatial restriction } \\
\text { (transmission easement) [m] }\end{array}$ & - & - & 15.3 & - & - & - & - & - \\
\hline \multicolumn{9}{|c|}{$\mathrm{C} 1$} \\
\hline & $400 \mathrm{kV}$ & $220 \mathrm{kV}$ & $110 \mathrm{kV}$ & $20 \mathrm{kV}$ & $15 \mathrm{kV}$ & $6 \mathrm{kV}$ & $3 \mathrm{kV}$ & $<1 \mathrm{kV}$ \\
\hline $\begin{array}{l}\text { Range of spatial restriction } \\
\text { (transmission easement) [m] }\end{array}$ & - & - & $8.0-11.0$ & 5.6 & 5.6 & 4.0 & 3.0 & 2.0 \\
\hline \multicolumn{9}{|c|}{ D1 } \\
\hline & $400 \mathrm{kV}$ & $220 \mathrm{kV}$ & $110 \mathrm{kV}$ & $20 \mathrm{kV}$ & $15 \mathrm{kV}$ & $6 \mathrm{kV}$ & $3 \mathrm{kV}$ & $<1 \mathrm{kV}$ \\
\hline $\begin{array}{l}\text { Range of spatial restriction } \\
\text { (transmission easement) [m] }\end{array}$ & - & - & $5.8-45.0$ & - & - & - & - & - \\
\hline \multicolumn{9}{|c|}{ E1 } \\
\hline & $400 \mathrm{kV}$ & $220 \mathrm{kV}$ & $110 \mathrm{kV}$ & $20 \mathrm{kV}$ & $15 \mathrm{kV}$ & $6 \mathrm{kV}$ & $3 \mathrm{kV}$ & $<1 \mathrm{kV}$ \\
\hline $\begin{array}{l}\text { Range of spatial restriction } \\
\text { (transmission easement) }[\mathrm{m}]\end{array}$ & - & - & - & 3.0 & 3.0 & 3.0 & 3.0 & 2.0 \\
\hline
\end{tabular}


Table 5. Range of spatial restrictions determined by electricity transmission companies depending on the voltage of cable power lines.

\begin{tabular}{|c|c|c|c|c|c|c|c|}
\hline \multicolumn{8}{|c|}{ A2 } \\
\hline & $110 \mathrm{kV}$ & $30 \mathrm{kV}$ & $20 \mathrm{kV}$ & $15 \mathrm{kV}$ & $10 \mathrm{kV}$ & $6 \mathrm{kV}$ & $<1 \mathrm{kV}$ \\
\hline $\begin{array}{l}\text { Range of spatial restriction } \\
\text { (transmission easement) [m] }\end{array}$ & 2.5 & - & 1.0 & 1.0 & - & 1.0 & 0.7 \\
\hline \multicolumn{8}{|c|}{ B2 } \\
\hline & $110 \mathrm{kV}$ & $30 \mathrm{kV}$ & $20 \mathrm{kV}$ & $15 \mathrm{kV}$ & $10 \mathrm{kV}$ & $6 \mathrm{kV}$ & $<1 \mathrm{kV}$ \\
\hline $\begin{array}{l}\text { Range of spatial restriction } \\
\text { (transmission easement) [m] }\end{array}$ & 6.0 & 6.0 & 3.0 & 3.0 & 3.0 & 3.0 & 1.0 \\
\hline \multicolumn{8}{|c|}{ C2 } \\
\hline & $110 \mathrm{kV}$ & $30 \mathrm{kV}$ & $20 \mathrm{kV}$ & $15 \mathrm{kV}$ & $10 \mathrm{kV}$ & $6 \mathrm{kV}$ & $<1 \mathrm{kV}$ \\
\hline $\begin{array}{l}\text { Range of spatial restriction } \\
\text { (transmission easement) [m] }\end{array}$ & 1.6 & - & - & $1.1-2.0$ & - & - & $1.0-1.3$ \\
\hline \multicolumn{8}{|c|}{ D2 } \\
\hline & $110 \mathrm{kV}$ & $30 \mathrm{kV}$ & $20 \mathrm{kV}$ & $15 \mathrm{kV}$ & $10 \mathrm{kV}$ & $6 \mathrm{kV}$ & $<1 \mathrm{kV}$ \\
\hline $\begin{array}{l}\text { Range of spatial restriction } \\
\text { (transmission easement) [m] }\end{array}$ & - & - & - & 1.0 & - & - & 0.6 \\
\hline \multicolumn{8}{|c|}{ E2 } \\
\hline & $110 \mathrm{kV}$ & $30 \mathrm{kV}$ & $20 \mathrm{kV}$ & $15 \mathrm{kV}$ & $10 \mathrm{kV}$ & $6 \mathrm{kV}$ & $<1 \mathrm{kV}$ \\
\hline $\begin{array}{l}\text { Range of spatial restriction } \\
\text { (transmission easement) [m] }\end{array}$ & - & - & - & 0.6 & - & - & - \\
\hline \multicolumn{8}{|c|}{ F2 } \\
\hline & $110 \mathrm{kV}$ & $30 \mathrm{kV}$ & $20 \mathrm{kV}$ & $15 \mathrm{kV}$ & $10 \mathrm{kV}$ & $6 \mathrm{kV}$ & $<1 \mathrm{kV}$ \\
\hline $\begin{array}{l}\text { Range of spatial restriction } \\
\text { (transmission easement) [m] }\end{array}$ & - & - & - & - & - & 6.0 & 3.0 \\
\hline \multicolumn{8}{|c|}{ G2 } \\
\hline & $110 \mathrm{kV}$ & $30 \mathrm{kV}$ & $20 \mathrm{kV}$ & $15 \mathrm{kV}$ & $10 \mathrm{kV}$ & $6 \mathrm{kV}$ & $<1 \mathrm{kV}$ \\
\hline $\begin{array}{l}\text { Range of spatial restriction } \\
\text { (transmission easement) [m] }\end{array}$ & - & - & - & - & - & 1.0 & - \\
\hline \multicolumn{8}{|c|}{ H2 } \\
\hline & $110 \mathrm{kV}$ & $30 \mathrm{kV}$ & $20 \mathrm{kV}$ & $15 \mathrm{kV}$ & $10 \mathrm{kV}$ & $6 \mathrm{kV}$ & $<1 \mathrm{kV}$ \\
\hline $\begin{array}{l}\text { Range of spatial restriction } \\
\text { (transmission easement) [m] }\end{array}$ & - & 0.5 & - & - & - & 0.5 & - \\
\hline \multicolumn{8}{|c|}{ I2 } \\
\hline & $110 \mathrm{kV}$ & $30 \mathrm{kV}$ & $20 \mathrm{kV}$ & $15 \mathrm{kV}$ & $10 \mathrm{kV}$ & $6 \mathrm{kV}$ & $<1 \mathrm{kV}$ \\
\hline $\begin{array}{l}\text { Range of spatial restriction } \\
\text { (transmission easement) [m] }\end{array}$ & - & - & - & - & 2.0 & - & - \\
\hline \multicolumn{8}{|c|}{$\mathrm{J} 2$} \\
\hline & $110 \mathrm{kV}$ & $30 \mathrm{kV}$ & $20 \mathrm{kV}$ & $15 \mathrm{kV}$ & $10 \mathrm{kV}$ & $6 \mathrm{kV}$ & $<1 \mathrm{kV}$ \\
\hline $\begin{array}{l}\text { Range of spatial restriction } \\
\text { (transmission easement) [m] }\end{array}$ & - & - & - & - & - & $1.0-3.0$ & $1.0-3.0$ \\
\hline
\end{tabular}

Table 6. Range of spatial restrictions determined by gas transmission companies depending on the technical parameters of gas-pipes constructed after 2001 with maximum working pressure >1.6 MPa.

\begin{tabular}{|c|c|c|c|c|}
\hline \multicolumn{5}{|c|}{ A3 } \\
\hline & $\mathrm{DN} \leq 150$ & $150<\mathrm{DN} \leq 300$ & $300<\mathrm{DN} \leq 500$ & $\mathrm{DN}>500$ \\
\hline $\begin{array}{l}\text { Range of spatial restriction } \\
\text { (transmission easement) }[\mathrm{m}]\end{array}$ & 4.0 & 6.0 & 6.0 & 6.0 \\
\hline \multicolumn{5}{|c|}{ B3 } \\
\hline & $\mathrm{DN} \leq 150$ & $150<\mathrm{DN} \leq 300$ & $300<\mathrm{DN} \leq 500$ & $\mathrm{DN}>500$ \\
\hline $\begin{array}{l}\text { Range of spatial restriction } \\
\text { (transmission easement) }[\mathrm{m}]\end{array}$ & 4.0 & 6.0 & 6.0 & 6.0 \\
\hline \multicolumn{5}{|c|}{$\mathrm{C3}$} \\
\hline & $\mathrm{DN} \leq 150$ & $150<\mathrm{DN} \leq 300$ & $300<\mathrm{DN} \leq 500$ & $\mathrm{DN}>500$ \\
\hline $\begin{array}{l}\text { Range of spatial restriction } \\
\text { (transmission easement) [m] }\end{array}$ & 4.0 & 6.0 & 8.0 & 12.0 \\
\hline
\end{tabular}


Table 7. Range of spatial restrictions specified by water supply transmission companies depending on the nominal diameter of the water pipeline.

\begin{tabular}{cccccc}
\hline \multicolumn{7}{c}{ A4 } \\
\hline & $\mathrm{DN}<300$ & $300 \leq \mathrm{DN}<500$ & $500 \leq \mathrm{DN}<600$ & $600 \leq \mathrm{DN}<800$ & $800=\mathrm{DN}$ \\
\hline $\begin{array}{c}\text { Range of spatial restriction } \\
\text { (transmission easement) [m] }\end{array}$ & 4.0 & 6.0 & 10.0 & 10.0 & 10.0 \\
\hline & $\mathrm{DN}<300$ & $300 \leq \mathrm{DN}<500$ & $500 \leq \mathrm{DN}<600$ & $600 \leq \mathrm{DN}<800$ & $800=\mathrm{DN}$ \\
\hline $\begin{array}{c}\text { Range of spatial restriction } \\
\text { (transmission easement) [m] }\end{array}$ & - & - & 5.0 & 6.0 & 8.0 \\
\hline
\end{tabular}

Companies justified the specified ranges with different factors. The justifications considering the same type of transmission device proved incoherent. The most frequently mentioned factors included: (1) maintaining the minimum distance of the device from buildings and other devices; (2) area necessary for eliminating failures; (3) location of the device on private land (underground, ground-bound, overhead); (4) maintaining a safe distance from tree crowns or the root system; (5) method of operation; and (6) applied safety measures.

\subsection{Results of the Analysis of the Case Studies}

The analysis of the case studies showed the following patterns. In the case of the first object $(400 \mathrm{kV}$ overhead power line), the required range of the established easement was $70 \mathrm{~m}$ ( $35 \mathrm{~m}$ on each side of the axis of the line). The buffer was determined over the entire length of the line $(21 \mathrm{~km})$, irrespective of land use or land management. The specified requirements were justified by the exceedance of acceptable noise levels and components of the electromagnetic field. Within the determined range, restrictions were introduced, including a ban on construction and use of buildings with rooms for permanent residence, and a ban on the maintenance of trees, bushes, and vegetation exceeding $5 \mathrm{~m}$ in height. The acceptance of bearing with the transmission devices constructed on private land, and the obligation of making such property available for operational and repair purposes was also required. The right to use private land involving the clearing of existing trees and bushes in the scope necessary for the construction of the line was reserved.

In reference to the second object ( $15 \mathrm{kV}$ cable power line), the transmission company required the establishment of a belt of restrictions of $1 \mathrm{~m}$ from the cable on the entire length of the route. The arranged restrictions involved a ban on construction and planting. An obligation of bearing with the presence of the device on private land, and providing access for the purpose of maintenance and repair was also introduced. The agreements establishing the easement stipulated that the range of expansion of the restrictions was determined according to "the rules of the company".

\section{Discussion}

\subsection{Assessment of the Study Results}

The review of international solutions showed the existence of many legal forms permitting the implementation of transmission investments on private land. The most common form proved to be easements. The established right is always accompanied by restrictions in the space of the land property. The range of the restrictions in certain countries is predefined (with the specification of particular values) and included in legal provisions (e.g., Latvia, Slovakia, and Bulgaria). In other countries, due to the lack of legal regulations, it is determined by transmission companies (e.g., Canada, Belarus, and Ukraine).

According to the analyses of the content of legal acts, norms, and technical guidelines performed by the authors (Section 4.1), there are no regulations in Poland that would impose such ranges. The new legal title introduced in the legislature in 2008 lacked executive acts that would specify issues related to the range of established transmission easements [91,92]. The need was recognised in the scope of 
works on the government's draft of the act on transmission corridors (2010-2013). The works were discontinued, however, and the project itself was cancelled in 2013 based on the non-constitutional character of some of the provisions. Moreover, no new content was added to the already existing regulations (Table 1) that would fill the gap.

The lack of certain regulations would perhaps not be so significant if the ranges determined by companies were coherent at the national scale and if they were substantively justified. Such a solution would constitute rational land management, and would provide vast possibilities for both the environment and the people who depend on it [31].

The survey, however, showed great divergencies in terms of scope. For a given type of transmission device with the same technical parameters, average differences proved to be double (Tables 4, 6 and 7), and in the extreme case-in reference to cable power lines-even 12-fold. Such results were observed in the case of a voltage of $30 \mathrm{kV}$ (answers from companies B2 and H2) and for a voltage of $6 \mathrm{kV}$ (answers from companies F2 and H2) (Table 5).

The justifications for the determination of the specified ranges resulting from the survey also revealed a lack of coherent assumptions. This is also confirmed by research conducted by Strzałka [93], who concludes that there is currently a lack of uniform, rational rules for determining the ranges of established easements in Poland. Particular companies recommend different methods and rules for their determination. No measures aimed at sustainable and rational land management are undertaken, however.

The completed questionnaires usually referred to the type of transmission device and its technical parameters, as well as the form it takes in the space of the land property (i.e., underground, ground-bound, or overhead device). The aforementioned factors, however, are obvious, and should constitute data providing the basis for further arrangements.

The answers provided also referred to the necessity to retain minimum distances from buildings. The distances result from provisions of relevant regulations concerning the rules of the design and construction of a device (Table 1). The specified buffers are of key importance due to the necessity of the provision of the safe operation of the device. The distances are therefore important in reference to devices with lower technical parameters. In reference to those with high parameters, their environmental impact is of key importance [73,74]. This considerably exceeds the area where the device is located and its safe operation. The range of influence particularly depends on the land use in the area subject to the regulation [75,76]. Its classification is determined by the division between building development areas and land accessible for people, e.g., agricultural, forest. According to the completed questionnaires, however, the factor was not considered by transmission companies. This is also confirmed by analyses of two case studies, where the establishment of transmission easement with the same range was demanded over the entire length of the route. In the case of one study object (overhead power line with a voltage of $400 \mathrm{kV}$ ) it was $70 \mathrm{~m}$ over the length of the $21 \mathrm{~km}$ of the route of the line irrespective of land use. In the case of the second study object (a cable power line with a voltage of $15 \mathrm{kV}$ ) it was $2 \mathrm{~m}$, with an emphasis on the fact that the range was determined according to the rules "determined by the company".

The study shows that the current situation is favourable for companies that determine the ranges of established transmission easements in Poland on their own terms. The analyses also showed that their demands are particularly harmful in reference to agricultural and forest land [3]. Ranges of restrictions determined for such land are too large, making its rational management difficult. Due to the common degradation of resources resulting from improper land use practices [94], such solutions should be prevented. In response to the issue, the authors proposed a methodology of determination of the range of transmission easement in reference to environmental, social, and economic aspects.

\subsection{Proposal of the Methodology of Determination of the Range of Transmission Easement in Poland}

The long-term economic competitiveness and security depends on the extent to which natural resources are used sustainably [95]. The conducted research and obtained results provided the basis 
for the development of a methodology of determination of the range of spatial restrictions caused by transmission infrastructure in Poland (transmission easement). The proposed concept is based on the combined interpretation of the content of relevant regulations included in Table 1 with consideration of the environmental, social, and economic aspects. It was assumed for the proposed concept to be uniform and coherent for all types of transmission devices, and to be objectively justified. The promoted idea should have an application analogical to the range of spatial restrictions determined in relation to the issued administrative decision restricting the use of the real estate [72].

In reference to the range of easement, due to the binding record of property boundaries in two dimensions in Poland [96-98], reference was made to ordinates $(x, y)$ in the binding rectangular ordinate system. The developed methodology involves four stages (Figure 1).

\begin{tabular}{|c|c|c|c|c|c|c|c|}
\hline STAGE I & \multicolumn{7}{|c|}{ Verification of establishment of the area of limited use } \\
\hline & \multicolumn{2}{|c|}{ Yes } & \multicolumn{2}{|c|}{$\begin{array}{l}1 \\
1 \\
1\end{array}$} & \multicolumn{2}{|c|}{ No } & \\
\hline STAGE II & \multicolumn{7}{|c|}{$\begin{array}{l}\text { Determination of the minimum range of restrictions (transmission easement) as a horizontal } \\
\text { projection of the outermost elements of the device on a plane }(\mathrm{x}, \mathrm{y})\end{array}$} \\
\hline \multicolumn{8}{|c|}{$T$} \\
\hline \multirow[t]{2}{*}{ STAGE III } & \multicolumn{7}{|c|}{$\begin{array}{l}\text { Verification of the land purpose in local spatial plans or in the case of its lack determination } \\
\text { whether a decision on the conditions of land development and management was issued } \\
\text { (alternatively the provisions of the study or actual manner of land use) }\end{array}$} \\
\hline & $\begin{array}{c}\text { Forest } \\
\text { areas }\end{array}$ & $\begin{array}{c}\text { Remaining } \\
\text { land }\end{array}$ & i & $\begin{array}{c}\text { Forest } \\
\text { areas }\end{array}$ & $\begin{array}{l}\text { Land for } \\
\text { building } \\
\text { development }\end{array}$ & $\begin{array}{l}\text { Land for } \\
\text { residential }\end{array}$ & $\begin{array}{c}\text { Remaining } \\
\text { land }\end{array}$ \\
\hline & & & 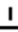 & & & & \\
\hline STAGE IV & \multicolumn{7}{|c|}{ Determination of potential additional expansions of the range of restrictions } \\
\hline $\begin{array}{l}\text { Minimum distances from } \\
\text { buildings/equipment } \\
\text { necessary for performing } \\
\text { exploitation activities } \\
\end{array}$ & + & + & $\begin{array}{l}T \\
1 \\
1\end{array}$ & + & + & + & + \\
\hline $\begin{array}{l}\text { Maintenance of } \\
\text { minimum distances } \\
\text { from trees / their root } \\
\text { system }\end{array}$ & + & - & $\begin{array}{l}1 \\
1 \\
1\end{array}$ & + & - & - & - \\
\hline $\begin{array}{l}\text { Threshold of exceeding } \\
\text { acceptable levels of noise }\end{array}$ & - & - & I & - & + & - & - \\
\hline $\begin{array}{l}\text { Threshold of exceeding } \\
\text { acceptable values of } \\
\text { components of the } \\
\text { electromagnetic field }\end{array}$ & - & - & $\begin{array}{l}\text { i } \\
\text { i } \\
\text { i }\end{array}$ & - & - & + & - \\
\hline
\end{tabular}

Figure 1. Methodology of the determination of the range of restrictions (transmission easement) for transmission devices.

Stage I involves the verification of whether an area of limited use was established for a given infrastructure [74]. It is established based on a resolution of the powiat or voivodship council with regard to the failure to meet environmental quality standards. This may result from exceeding acceptable thresholds for components of electromagnetic fields [75] and noise level [76]. The area can in particular accompany overhead power lines with high and highest voltage.

Stage II involves the determination of the minimum range of restrictions (scope of easement execution) as a horizontal projection of the outermost elements of the device on a plane $(x, y)$. The restrictions are related to the physical existence of the device on private land.

Stage III involves the verification of the purpose of land in local spatial plans or determination of the method of land management. The analysis of legal provisions showed the necessity to qualify land to one of four groups, namely: (1) forest land, (2) land for residential construction, (3) land for building construction (defined as land for construction of residential buildings, hospitals and public nursing homes, buildings related to permanent or temporary stays of children and youngsters, and land for rehabilitation, recreational and holiday, or residential and service purposes), and (4) other land. If the area of limited use was established (Stage I), the land division due to land use only requires the designation of forest areas. 
Stage IV involves the determination of a potential additional expansion of the range of restrictions (scope of easement execution). The restrictions can result from retaining safe distances from other objects (Table 1), and the need to perform operational measures, which would then concern all types of land. In the case of forest land, such an expansion additionally results from the need to clear trees, and the necessity to maintain the minimum distance from trees and/or their root systems (Table 1). Moreover, in the case of a lack of the established area of limited use, the range of restrictions should be also expanded due to the exceedance of acceptable noise levels. The situation concerns only land for building construction (in accordance with the description included in Stage III). In reference to the remaining land, the acceptable threshold noise levels are not specified [76]. The procedure should be analogical in the case of exceeding acceptable values of components of the electromagnetic field, whereas threshold physical parameters characterising the effect of electromagnetic fields on the environment are applied exclusively on land for residential construction [75].

\subsection{Testing the Developed Methodology on a Model Object}

The testing of the proposed methodology for determining the range of transmission easement was performed on a model object-a double track $400 \mathrm{kV}$ overhead power line. The selection of the aforementioned object was based on the choice of a device with the highest technical parameters in order to illustrate the scale of differences between the ranges currently established by companies (Table 4, the first case study) and those resulting from the developed concept.

The determination of the range of transmission easement on the model object involved adopting the following assumptions:

1. Type of transmission device: overhead power line.

2. Technical parameters: double track $400 \mathrm{kV}$ power line, constructed on grid mast series E33 (developed on reinforced concrete foundations). The minimum distance between the phase conductor and the ground is $13.4 \mathrm{~m}$. The span length is $350 \mathrm{~m}-500 \mathrm{~m}$. The maximum reach (projection) of the outer wires of the line on the xy-plane is $21.06 \mathrm{~m}$ (10.53 $\mathrm{m}$ from the line axis).

3. It was assumed that no area of limited use was established for said power line.

4. It was assumed that the model object runs through three cadastral parcels, and that the analysed area is subject to a local spatial development plan stipulating that: (a) cadastral parcel No. 1 is located in a single family housing area; (b) cadastral parcel No. 2 is located in an agricultural area; and (c) cadastral parcel No. 3 is located in a forest area.

5. It was assumed that operation activities would be performed by means of a vehicle with a maximum width of $2.50 \mathrm{~m}$ due to the width of the traffic lanes and would concern each parcel irrespective of the land use. Considering the movement of the vehicle on both sides of the device, and the possibility of its rational manoeuvring, the range of $27.00 \mathrm{~m}$ (13.5 $\mathrm{m}$ from the line axis) was adopted.

6. The width of the belt of tree clearing was calculated in accordance with the following formula [82]:

$$
S w=B+2 x\left(2,5+\frac{U}{150}\right)[m]
$$

where $B$ is the distance between the outer working wires $(21.06 \mathrm{~m})$ and $U$ is the highest possible nominal voltage of the network, i.e., $420 \mathrm{kV}$. Considering the above, the belt of tree clearing was determined for $31.66 \mathrm{~m} \approx 31.70 \mathrm{~m}$ (this concerns only cadastral parcel No. 3).

7. The noise level for the model power line was adopted following Jaworowska-Jurewicz [99], who for an analogical line with the same technical parameters and identical technical specifics, in an environmental impact forecast, determined it to be in a range of $28 \mathrm{~dB}$ to $35 \mathrm{~dB}$ during good weather conditions and above $50 \mathrm{~dB}$ exclusively during bad weather. The author demonstrated that admissible noise levels were exceeded at a maximum distance of up to $20 \mathrm{~m}$ from the line axis. The above arrangements, however, only concern land for building development (cadastral 
parcel No. 1). On agricultural and forest land, the noise level is not subject to any norms in Poland (Table 3).

8. The intensity of the magnetic field for the model power line was adopted following Jaworowska-Jurewicz [99], who for an analogical line determined it for max. $\mathrm{H}=24.9 \mathrm{~A} / \mathrm{m}$. The admissible level of intensity of the magnetic field (Table 2) was not exceeded anywhere. Therefore, the parameter has no impact on the range of the established easement.

9. The intensity of electric field for the model power line was adopted following Jaworowska-Jurewicz [99] for max. $E=4.22 \mathrm{kV} / \mathrm{m}$. At the threshold value of $1 \mathrm{kV} / \mathrm{m}$ for areas of residential building development (Table 2), the author determined that the intensity was exceeded at a maximum distance of up to $25 \mathrm{~m}$ from the line axis. The above determinations, however, only concern cadastral parcel No. 1. For the remaining cadastral parcels No. 2 and 3, threshold values for the intensity of the electric field have no effect on the range of transmission easement. In areas accessible for people (agricultural and forest land), the parameter cannot exceed $10 \mathrm{kV} / \mathrm{m}$ (Table 2).

The above assumptions permitted the determination of the ranges of transmission easement for the model object (Figure 2) in accordance with the methodology developed by the authors (Figure 1).

\begin{tabular}{|c|c|c|c|}
\hline STAGE I & \multicolumn{3}{|c|}{ Verification of establishment of the area of limited use } \\
\hline & & \multicolumn{2}{|l|}{ No } \\
\hline STAGE II & \multicolumn{3}{|c|}{$\begin{array}{l}\text { Determination of the minimum range of restrictions (transmission easement) as a horizontal } \\
\text { projection of the outermost elements of the device on a plane }(\mathrm{x}, \mathrm{y})\end{array}$} \\
\hline & \multicolumn{3}{|c|}{$21,06 \mathrm{~m}$} \\
\hline STAGE III & \multicolumn{3}{|c|}{ Verification of the land purpose in local spatial plans } \\
\hline & $\begin{array}{c}\text { Land for residential } \\
\text { - cadastral parcel No. } 1 \\
\end{array}$ & $\begin{array}{l}\text { Agricultural } \\
\text { areas - cadastral } \\
\text { parcel No. } 2\end{array}$ & $\begin{array}{c}\text { Forest areas } \\
\text { - cadastral parcel } \\
\text { No. } 3\end{array}$ \\
\hline STAGE IV & \multicolumn{3}{|c|}{ Determination of potential additional expansions of the scope of transmission easement } \\
\hline $\begin{array}{l}\text { Equipment necessary } \\
\text { for performing } \\
\text { exploitation activities }\end{array}$ & $\stackrel{+}{\stackrel{+}{\text { Extension to } 27,00 \mathrm{~m}}}$ & $\stackrel{+}{\stackrel{+}{\text { Extension to } 27,00 \mathrm{~m}}}$ & $\stackrel{+}{\stackrel{+}{\text { Extension to } 27,00 \mathrm{~m}}}$ \\
\hline $\begin{array}{c}\text { Maintenance of } \\
\text { minimum distances } \\
\text { from trees } / \text { their root } \\
\text { system }\end{array}$ & - & - & $\stackrel{+}{\text { Extension to } 31,70 \mathrm{~m}}$ \\
\hline $\begin{array}{l}\text { Threshold of } \\
\text { exceeding acceptable } \\
\text { levels of noise }\end{array}$ & $\stackrel{+}{+}$ Extension to $40,00 \mathrm{~m}$ & - & - \\
\hline $\begin{array}{c}\text { Threshold of } \\
\text { exceeding acceptable } \\
\text { values of components } \\
\text { of the electromagnetic } \\
\text { field }\end{array}$ & $\stackrel{+}{\stackrel{+}{\text { Extension to }} 50,00 \mathrm{~m}}$ & - & - \\
\hline
\end{tabular}

Figure 2. Determination of the range of transmission easement for the model object.

Finally, in accordance with the proposed methodology, the following ranges of transmission easement were obtained: (a) cadastral parcel No. 1, 50.00 m; (b) cadastral parcel No. 2, 27.00 m; and (c) cadastral parcel No. 3, $31.70 \mathrm{~m}$.

\section{Conclusions}

Due to their economic importance, easements are usually of permanent character. Therefore, restrictions imposed on real estate are permanent as well. At the same time, a form of land use may be regarded as sustainable if no permanent or progressive deterioration of its suitability to the land occurs over a reasonably lengthy period of future [31]. Due to the above, all legal actions with consequences in the form of land use must be rational and consider broadly defined environmental aspects [91]. 
The article presents the analysis of the rules of determination of the ranges of restrictions resulting from established transmission easements in Poland. Analyses of legal acts, norms and technical guidelines, survey results, and case studies showed the arbitrary approach of transmission companies to the determined ranges. This confirmed the presumptions of the authors concerning the lack of coherent rules for their determination, as well as a lack of substantive justification of the demands of the companies. It also evidenced the need for rational land use (including its rational restriction), pointing to the current particularly harmful solutions in reference to agricultural and forestry areas.

The methodology of determination of the range of restrictions accompanying easements developed in accordance with the objective of the article showed that next to basic factors, such as the type of transmission device and its technical parameters, the range particularly depends on the land use, as confirmed by the test study on the model object.

The methodology for determining the scope of transmission easement proposed by the authors can constitute a coherent and uniform model of action for all transmission companies in Poland. The proposed concept draws attention to the environmental problem resulting from the demands of entrepreneurs and the passive approach of political institutions. In the pragmatic aspect, it offers the chance to overcome the "information chaos" accompanying currently determined ranges. As a consequence, it can constitute base material for works of relevant institutions on legal provisions that would regulate the issues.

The idea discussed herein can also contribute to an increase in the awareness of land owners in reference to the properties and range of restrictions resulting from the established easement. With proper implementation, it can also be introduced in a similar institutional-legal environment in other countries.

Author Contributions: Conceptualization, N.S. and K.S.M.; methodology, N.S.; formal analysis, N.S. and K.S.M.; investigation, N.S.; resources, N.S. and K.S.M.; data curation, N.S. and J.W.L.; writing - original draft preparation, N.S.; writing-review and editing, N.S., K.S.M. and J.W.L.; visualization, N.S., K.S.M. and J.W.L.; supervision, N.S.; project administration, N.S. and K.S.M.; funding acquisition, N.S. and K.S.M.

Funding: This research was funded by the Faculty of Geodesy and Cartography of Warsaw University of Technology from statutory funds.

Acknowledgments: We would like to express our gratitude to Jarosław Legat (Ontario, Canada), Velta Parsova (Latvia), L'ubica Hudecová, Ph.D. (Slovakia), Milena Moteva (Bulgaria), Tatiana Borzdova and Sergey Shavrov (Belarus), and Mykola Malashevskyi (Ukraine) for assistance in obtaining data in the scope of easements established for transmission companies and the rules of determination of the range of restrictions (easement) resulting from the existence of transmission infrastructure on private land.

Conflicts of Interest: The authors declare no conflict of interest.

\section{References and Notes}

1. Borcz, Z. Infrastruktura Terenów Wiejskich (in Polish) [Infrastructure of Rural Areas]; Wydawnictwo Akademii Rolniczej we Wrocławiu: Wrocław, Poland, 2000.

2. Kowalczyk, C.; Konieczny, D.; Nowak, M.; Adamuscind, A.; Goleje, J. Economic effects transmission easement on agricultural lands in Poland. In Proceedings of the Economic Science for Rural Development, Jelgava, Latvia, 21-22 April 2016.

3. Sajnóg, N.; Sobolewska-Mikulska, K. Oddziaływanie infrastruktury przesyłowej na przestrzeń rolniczą (in Polish) [Impacts of the transmission infrastructure on the agricultural space]. Infrastrukt. I Ekol. Teren. Wiej. 2017, I/1, 119-128. [CrossRef]

4. Hernik, J.; Gawroński, K.; Dixon-Gough, R. Social and economic conflicts between cultural landscapes and rural communities in the English and Polish systems. Land Use Policy 2013, 30, 800-813. [CrossRef]

5. Senetra, A.; Szczepańska, A.; Wasilewicz-Pszczółkowska, M. Analysis of changes in the land use structure of developed and urban areas in Eastern Poland. Bull. Geogr. Socio-Econ. Ser. 2014, 24, 219-230. [CrossRef]

6. Raszeja, E.; Wilkaniec, A.; Szczepańska, M. Management of landscape resources as an element of development of communes in the Poznan agglomeration-declarativeness of assumptions vs realities of spatial policy. Przestrz. I Forma 2017, 29, 135-152. [CrossRef] 
7. Czerna-Grygiel, J. Finansowanie infrastruktury technicznej dla zrównoważonego rozwoju (in Polish) [Financing of technical infrastructure for sustainable development]. Zesz. Nauk. Uniw. Szczecińskiego. Finans. Rynk. Finans. Ubezpieczenia 2013, 62, 21-28.

8. United Nations. Transforming Our World: The 2030 Agenda for Sustainable Development; A/RES/70/1; United Nations: New York, NY, USA, 2015.

9. Drumheller, B.; Quaid, A.; Wyman, M.; Liljenwall, J.; Young, A. Sustainable Transportation Options for Protecting the Climate; International Council for Local Environmental Initiatives: Berkeley, CA, USA, 2001.

10. Merkisz-Guranowska, A.; Merkisz, J.; Kozak, M.; Jacyna, M. Development of a sustainable road transport system. In Urban Transport XIX; WIT Transactions on the Built Environment; Wit Press: Southampton, UK, 2013; pp. 507-517. [CrossRef]

11. Xu, X.; Chen, A.; Yang, C. A Review of Sustainable Network Design for Road Networks. KSCE J. Civ. Eng. 2016, 20, 1084-1098. [CrossRef]

12. Puodziukas, V.; Svarpliene, A.; Aivaras Braga, A. Measures for sustainable development of road network. Transp. Res. Procedia 2016, 14, 965-972. [CrossRef]

13. Lopez, E.; Monzon, A. Integration of sustainability issues in strategic transportation planning: A multi-criteria model for the assessment of transport infrastructure plans. Comput. Aided Civ. Infrastruct. Eng. 2010, 25, 440-451. [CrossRef]

14. Ford, A.C.; Barr, S.L.; Dawson, R.J.; James, F. Transport Accessibility Analysis Using GIS: Assessing Sustainable Transport in London. ISPRS Int. J. Geo-Inf. 2015, 4, 124-149. [CrossRef]

15. Krupowicz, W.; Sobolewska-Mikulska, K.; Burinskiene, M. Modern trends in road network development in rural areas. Balt. J. Road Bridge Eng. 2017, 12, 48-56. [CrossRef]

16. Directive (EU) 2018/2001 of the European Parliament and of the Council of 11 December 2018 on the Promotion of the Use of Energy from Renewable Sources. Available online: https://www.europeansources.info/ record/directive-eu-2018-2001-on-the-promotion-of-the-use-of-energy-from-renewable-sources/ (accessed on 9 July 2019).

17. Flodberg, K.; Blomsterberg, A.; Dubois, M.C. Low-energy office buildings using existing technology: Simulations with low internal heat gains. Int. J. Energy Environ. Eng. 2012, 3, 1-9. [CrossRef]

18. Lean, H.H.; Smyth, R. Will policies to promote renewable electricity generation be effective? Evidence from panel stationarity and unit root tests for 115 countries. Renew. Sustain. Energy Rev. 2013, 22, 371-379. [CrossRef]

19. Menegaki, A.N. Growth and renewable energy in Europe: Benchmarking with data envelopment analysis. Renew. Energy 2013, 60, 363-369. [CrossRef]

20. Jacobsen, H.K.; Pade, L.L.; Schrder, S.T.; Kitzing, L. Cooperation mechanisms to achieve EU renewable targets. Renew. Energy 2014, 63, 345-352. [CrossRef]

21. Banister, D. Assessing the reality-Transport and land use planning to achieve sustainability. J. Transp. Land Use 2012, 5, 1-14. [CrossRef]

22. Hurtado, A.; Eguilior, S.; Recreo, F. Methodological development of a probabilistic model for $\mathrm{CO}_{2}$ geological storage safety assessment. Int. J. Energy Environ. Eng. 2014, 5, 84. [CrossRef]

23. Rezaei, M.S.; Chaharsooghi, K.; Abbaszadeh, P. The Role of Renewable Energies in Sustainable Development: Case Study Iran. Iran. J. Energy Environ. 2013, 4, 320-329. [CrossRef]

24. Pan, H.; Page, J.; Zhang, L.; Chen, S.; Cong, D.; Destouni, G.; Kalantari, Z.; Deal, B. Using comparative socio-ecological modeling to support Climate Action Planning (CAP). J. Clean. Prod. 2019, 232, 30-42. [CrossRef]

25. Mrowiec, M.; Ociepa, E.; Malmur, R.; Deska, I. Sustainable Water Management in Cities under Climate Changes. Probl. Sustain. Dev. 2018, 13, 133-138.

26. Koop, S.H.A.; van Leeuwen, C.J. The challenges of water, waste and climate change in cities. Environ. Dev. Sustain. 2017, 19, 385-418. [CrossRef]

27. Hurlimann, A.; Wilson, E. Sustainable Urban Water Management under a Changing Climate: The Role of Spatial Planning. Water 2018, 10, 546. [CrossRef]

28. Malekpour, S.; Brown, R.R.; de Haan, F.J. Strategic planning of urban infrastructure for environmental sustainability: Understanding the past to intervene for the future. Cities 2015, 46, 67-75. [CrossRef]

29. Truffer, B.; Störmer, E.; Maurer, M.; Ruef, A. Local Strategic Planning Processes and Sustainability Transitions in Infrastructure Sectors. Environ. Policy Gov. 2010, 20, 258-269. [CrossRef] 
30. Gibberd, J. Strengthening Sustainability Planning: The City Capability Framework. Procedia Eng. 2017, 198, 200-211. [CrossRef]

31. Smyth, A.J.; Dumanski, J. FESLM: An International Framework for Evaluating Sustainable Land Management; World Soil Resources Report; Food and Agriculture Organization of the United Nations: Rome, Italy, 1993.

32. Williamson, J.F.; Enemark, S.; Wallace, J.; Rajabifard, A. Land Administration for Sustainable Development. In Proceedings of the FIG Congress 2010 Facing the Challenges-Building the Capacity, Sydney, Australia, 11-16 April 2010.

33. Konieczny, D. Odszkodowania i wynagrodzenia przy ustanawianiu służebności przesyłu (in Polish) [Compensation and remuneration in the case of the establishment of the transmission servitude]. Studia I Mater. Tow. Nauk. Nieruchom. 2012, 20,131-141.

34. Konieczny, D.; Kowalczyk, C. Utility easement issues and transmission infrastructure in Poland. In Proceedings of the International Conference on Environmental Engineering, Vilnius, Lithuania, 22-24 May 2014.

35. Sajnóg, N. Impacts of the transmission infrastructure on spatial conditions and real estate values against polish solutions. In Proceedings of the Geodesy and Mine Surveing, 15th International Multidisciplinary Scientific GeoConference SGEM 2015, Albena, Bulgaria, 18-24 June 2015. [CrossRef]

36. Simons, R.A. The Effect of Pipeline Ruptures on Noncontaminated Residential Easementholding Property in Fairfax County. Apprais. J. 1999, 67, 255-263.

37. Des Rosiers, F. Power Lines, Visual Encumbrance and House Values: A Microspatial Approach to Impact Measurement. J. Real Estate Res. 2002, 23, 275-301.

38. Sajnóg, N. The influence of landscape damages resulting from the presence of transmission devices in real estate on its value-Situation in Poland. In Proceedings of the Geodesy and Mine Surveing, 17th International Multidisciplinary Scientific GeoConference SGEM 2017, Albena, Bulgaria, 29 June-5 July 2017. [CrossRef]

39. Kowicki, M. Wieś Przyszłości-Próba Określenia jej Kształtu Planistyczno-Przestrzennego i Architektonicznego (in Polish) [Rural Areas of the Future-Attempt to Determine its Planning, Spatial, and Architectonic Shape]; Wilkin, J., Ed.; Fundusz Współpracy: Warsaw, Poland, 2005; pp. 199-207.

40. Raszeja, E. W poszukiwaniu ładu i autentyczności [In search for order and authenticity]. In Polska wieś 2025. Wizja rozwoju (in Polish) [Polish rural areas 2025. Vision of development]; Wilkin, J., Ed.; Fundusz Współpracy: Warsaw, Poland, 2005; pp. 191-198.

41. Kupidura, A.; Łuczewski, M.; Home, R.; Kupidura, P. Public perceptions of rural landscapes in land consolidation procedures in Poland. Land Use Policy 2014, 39, 313-319. [CrossRef]

42. Jorgensen, B.S.; Stedman, R.C. Sense of place as an attitude: Lakeshore owners' attitudes towards their properties. J. Environ. Psychol. 2001, 21, 233-248. [CrossRef]

43. Moore-Colyer, R.; Scott, A. What kind of landscape do we want? Past, present and future perspectives. Landsc. Res. 2005, 30, 501-523. [CrossRef]

44. Bastian, C.T.; Keske, C.M.H.; McLeod, D.M.; Hoag, D.L. Landowner and land trust agent preferences for conservation easement: Implications for sustainable land uses and landscape. Landsc. Urban Plan. 2017, 157, 1-13. [CrossRef]

45. Stopar, I.; Šubic Kovač, M. Land valuation in case of easement: The case study in Slovenia. Geod. Vestn. 2016, 60, 685-702. [CrossRef]

46. Šnajberg, O. Valuation of real estate with easement. Procedia Econ. Financ. 2015, 25, 420-427. [CrossRef]

47. Butryn, K.; Preweda, E. Selected Issues of Establishing and Functioning of the Transmission Easement. Geomat. Environ. Eng. 2016, 10, 33-43. [CrossRef]

48. Polasky, S.; Johnson, K.; Keeler, B.; Kovacs, K.; Nelson, E.; Pennington, D.; Withey, J. Are investments to promote biodiversity conservation and ecosystem services aligned? Oxf. Rev. Econ. Policy 2012, 28, 139-163. [CrossRef]

49. Greene, R.P.; Stager, J. Rangeland to cropland conservation as replacement land for prime farmland lost to urban development. Soc. Sci. J. 2001, 38, 543-555. [CrossRef]

50. Lubowski, R.N.; Plantinga, A.J.; Stavins, R.N. What drives land use change in the United States? A national analysis of landowner decisions. Land Econ. 2008, 84, 529-550. [CrossRef]

51. Milder, J.C.; Clark, S. Conservation development practices, extent, and land-use effects in The United States. Conserv. Biol. 2011, 25, 697-707. [CrossRef]

52. Bojarski, W. Prawo Rzymskie (in Polish) [Roman Law]; Wolters Kluwer Polska SA: Gdańsk, Poland, 1999. 
53. Lewandowski, P. Stużebność Przesyłu w Prawie Polskim (in Polish) [Transmission Easement in the Polish Law]; Wolters Kluwer Polska SA: Gdańsk, Poland, 2014.

54. Depoorter, B.W.F.; Parisi, F. Fragmentation of Property Rights: A Functional Interpretation of the Law of Servitudes. John M. Olin Cent. Stud. Law Econ. Public Policy Work. Pap. 2003, 3, 1-41.

55. Warciński, M. Stużebności Gruntowe Wedtug Kodeksu Cywilnego (in Polish) [Land Easements Pursuant to the Civil Code]; Wolters Kluwer Polska SA: Gdańsk, Poland, 2013.

56. Bełej, M.; Piotrowska, R.; Źróbek, R. Rola i pozycja geodezji w zapewnieniu bezpieczeństwa rejestracji praw do nieruchomości w krajach Unii Europejskiej (in Polish) [Role and position of geodesy in ensuring safety of registration of rights to land property in the countries of the European Union]. Przeglad Geod. 2003, 75, 10-15.

57. Sajnóg, N.; Sobolewska-Mikulska, K. Registration of easements established for transmission companies-Case study of Poland and Canada. Geod. Cartogr. 2018, 67, 1-12. [CrossRef]

58. Civil Law Act (Journal of Laws of 2017, with Amendments), Latvia. 1937.

59. Protection Zone Law (Journal of Laws of 2016, with Amendments), Latvia. 1997.

60. Civil Code Act (Act No. 40/1964 Coll. Civil Code, with Amendments), National Council of the Slovak Republic: Bratislava, Slovakia, 1964.

61. Act on Water (Act No. 184/2002 Coll. on Water and Amendments to Certain Acts, with Amendments), National Council of the Slovak Republic: Bratislava, Slovakia, 2002.

62. Poldaufová, O.; Katona, P. Vecné bremená s verejnoprávnym prvkom (in Slovak). Slovenský Geodet Kartograf Bull. Komory Geodetov Kartografov 2016, 2, 9-11.

63. Act on Energy (Act No. 251/2012 Coll. on Energetics, with Amendments), National Council of the Slovak Republic: Bratislava, Slovakia, 2012.

64. Hudecova, L.; Geisse, R. Displaying of easements in vector cadastral maps. In Proceedings of the 10th International Scientific and Professional Conference on Geodesy, Cartography and Geoinformatics, Nízke Tatry, Bratislava, Slovakia, 10-13 October 2017.

65. Water Act (State Gazette Issue 67/27 July 1999, Last am. and Suppl. State Gazette Issue 96/1 December 2017, with Amendments), Sofia, Bulgaria, 1999.

66. Spatial Planning Act (State Gazette Issue 1/1 January 2001, Last am. and Suppl. State Gazette Issue 21/9 March 2018, with Amendments), Sofia, Bulgaria, 2001.

67. Energy Act (State Gazette Issue 107/9 December 2003, Last am. State Gazette 7/7 January 2018, with Amendments), Sofia, Bulgaria, 2003.

68. Land Code of Ukraine (Act. No. 2768-III the Land Code of Ukraine: Code of Ukraine of 25.10.2001, with Amendments), Verkhovna Rada of Ukraine. Bulletin of the Verkhovna Rada of Ukraine, Ukraine. 2001.

69. Standardisation Act (Journal of Laws of 2015 Item 1483), Poland. 2002. Available online: http://prawo.sejm. gov.pl/isap.nsf/DocDetails.xsp?id=WDU20021691386 (accessed on 9 July 2019).

70. Civil Code Act (Journal of Laws of 2018, Item 1025, 1104, 1629, 2073, 2244, with Amendments), Poland. 1964. Available online: http://prawo.sejm.gov.pl/isap.nsf/DocDetails.xsp?id=WDU19640160093 (accessed on 9 July 2019).

71. Act on the Amendment of the Civil Code Act and Certain Other Acts (Journal of Laws of 2008, No. 116, item 731), Poland. 2008. Available online: http://prawo.sejm.gov.pl/isap.nsf/DocDetails.xsp?id=WDU20081160731 (accessed on 9 July 2019).

72. Act on Real Estate Management (Journal of Laws of 2018, Item 2204, 2348, with Amendments), Poland. 1997. Available online: http://prawo.sejm.gov.pl/isap.nsf/DocDetails.xsp?id=WDU19971150741 (accessed on 9 July 2019).

73. Act Concerning Sharing Information about the Natural Environment and Its Preservation, Social Involvement in Protecting Nature as Well as Estimates with Regards to the Impact on the Natural Environment (Journal of Laws of 2018, item 2081, with Amendments), Poland. 2008. Available online: http://prawo.sejm.gov.pl/isap.nsf/ DocDetails.xsp?id=WDU20081991227 (accessed on 9 July 2019).

74. Environmental Protection Act (Journal of Laws of 2018, item 799, 1356, 1479, 1564, 1590, 1592, 1648, 1722, 2161, 2533, with Amendments), Poland. 2001. Available online: http://prawo.sejm.gov.pl/isap.nsf/DocDetails.xsp? id=WDU20010620627 (accessed on 9 July 2019). 
75. Regulation of the Ministry of the Environment on Accessible Levels of Electromagnetic Fields in the Environment and Manners of Verification of Maintenance of Such Levels (Journal of Laws of 2003, No. 192, item 1883), Poland. 2003. Available online: http://prawo.sejm.gov.pl/isap.nsf/DocDetails.xsp?id=WDU20031921883 (accessed on 9 July 2019).

76. Regulation of the Ministry of the Environment on Acceptable Levels of Noise in the Environment (Journal of Laws of 2007, No. 120, Item 826, with Amendments), Poland. 2007. Available online: http://prawo.sejm.gov.pl/isap. nsf/DocDetails.xsp?id=WDU20071200826 (accessed on 9 July 2019).

77. Regulation of the Ministry of the Economy on Technical Conditions Concerning Gas Networks and Their Location (Journal of Laws of 2013, No. Item 640), Poland. 2013. Available online: http://prawo.sejm.gov.pl/isap.nsf/ DocDetails.xsp?id=WDU20130000640 (accessed on 9 July 2019).

78. Regulation of the Ministry of the Economy on Technical Conditions Concerning Liquid Fuel Bases and Stations, Long-Distance Transmission Pipelines for Transport of Petroleum and Petroleum Products, and Their Location (Journal of Laws of 2005, No. 243, Item 2063, with Amendments), Poland. 2005. Available online: http://prawo.sejm.gov.pl/isap.nsf/DocDetails.xsp?id=WDU20052432063 (accessed on 9 July 2019).

79. Regulation of the Ministry of Infrastructure on Technical Conditions Concerning Telecommunication Building Objects and Their Location (Journal of Laws of 2005, No. 219, Item 1864), Poland. 2005. Available online: http://prawo.sejm.gov.pl/isap.nsf/DocDetails.xsp?id=WDU20052191864 (accessed on 9 July 2019).

80. Norm, PN-E-05100-1, Overhead Power Lines. Design and Construction Alternate Current lines with Bare Working Cables, Poland. 1998. Available online: https://sklep.pkn.pl/pn-e-05100-1-1998p.html (accessed on 9 July 2019).

81. Norm, N-SEP-E-003, Overhead Power Lines. Design and Construction Alternate Current Lines with Fully Isolated Cables and Partially Isolated Cables, Poland. 2003. Available online: https://sklep.cosiw.pl/n-sep-e-003e-do-pobraniaelektroenergetyczne-linie-napowietrzne-projektowanie-ibudowa-linie-pradu-przemiennego-z-przewodami-pelnoizolowanymi-oraz-z-p-261.html (accessed on 9 July 2019).

82. Norm, PN-EN 50341-3-22:2010, Overhead Power Lines of Alternate Current Above 45 kV, Part 3: Collection of National Normative Conditions National Normative Conditions for Poland, Poland. 2010. Available online: http://sklep.pkn.pl/pn-en-50341-3-22-2010p.html (accessed on 9 July 2019).

83. Norm, PN-EN 50341-1:2013-03, Overhead Power Lines of ALTERNATE current above 1 kV, Poland. 2013. Available online: https://sklep.pkn.pl/pn-en-50341-1-2013-03p.html (accessed on 9 July 2019).

84. Norm, N SEP-E 004, Power and Signalling Cable Lines, Design and Construction, Poland. 2003. Available online: https://sklep.cosiw.pl/n-sep-e-004-elektroenergetyczne-i-sygnalizacyjne-linie-kabloweprojektowanie-i-budowa-p-11.html (accessed on 9 July 2019).

85. Guidelines of the Central Research and Development Centre of Installation Technology INSTAL, Volume No. 3, Technical Conditions of Performance and Commissioning of Water Supply Networks; Central Research and Development Centre: Warsaw, Poland, 2001.

86. Guidelines of the Central Research and Development Centre of Installation Technology, Volume No. 9, Technical Conditions of Performance and Commissioning of Sewage Pipelines; Central Research and Development Centre: Warsaw, Poland, 2003.

87. Guidelines of the Central Research and Development Centre of Installation Technology INSTAL, Volume No. 4, Technical Conditions of Performance and Commissioning of Heating Networks Composed of Pipes and Preisolated Elements; Central Research and Development Centre: Warsaw, Poland, 2002.

88. Gołba, Z. Służebności Gruntowe, Drogowe, Osobiste I Przesyłu (in Polish) [Land, Road, Personal, and Transmission Easements]; LexisNexis: Warsaw, Poland, 2011.

89. Rakoczy, B. Stużebność Przesyłu w Praktyce (in Polish) [Transmission Easement in Practice]; LexisNexis: Warsaw, Poland, 2012.

90. Groves, R.M. Nonresponse rates and nonresponse bias in household surveys. Public Opin. Q. 2006, 70, 646-675. [CrossRef]

91. Sajnóg, N. Metodyka Określania Zasięgu Służebności Przesyłu dla Potrzeb Rejestracji w Katastrze Nieruchomości (in Polish) [Methodology of Determination of the Range of Transmission Easement for the Purposes of Registration in the Cadastre]. Ph.D. Thesis, Warsaw University of Technology, Warsaw, Poland, 28 September 2016. 
92. Butryn, K. An Analysis of Arrangements of the Local Spatial Management Plans in the Context of Determining Coverage of Transmission Easements-The Example of the City of Krakow. Geomat. Environ. Eng. 2016, 10, 49-60. [CrossRef]

93. Strzałka, J. Zasady Wyznaczania Pasów Służebności dla linii Energetycznych (in Polish) [Rules of Determination of Belts of Easement for Power Lines]. 2015. Available online: http://www.map. piib.org.pl/uploads/pliki/materia\%C5\%82y\%20szkoleniowe/2018/11Strza\%C5\%82ka\%20J_ZASADY\% 20WYZNACZANIA\%20PAS\%C3\%93W\%20S\%C5\%81U\%C5\%BBEBNO\%C5\%9ACI-popr_2.pdf (accessed on 9 July 2019).

94. Motavalli, P.; Nelson, K.; Udawatta, R.; Jose, S.; Bardhan, S. Global achievements in sustainable land management. Int. Soil Water Conserv. Res. 2013, 1,1-10. [CrossRef]

95. Maes, J.; Jacobs, S. Nature-Based Solutions for Europe's Sustainable Development. Conserv. Lett. 2017, 10, 121-124. [CrossRef]

96. Siejka, M.; Ślusarski, M.; Zygmunt, M. Kataster wielowymiarowy, możliwość wdrożenia w Polsce (in Polish) [Multidimensional cadastre, implementation possibilities in Poland]. Infrastrukt. I Ekol. Teren. Wiej. 2014, II/2/2014, 557-569. [CrossRef]

97. Bydłosz, J. Developing the Polish Cadastral Model towards a 3D Cadastre. In Proceedings of the 5th International FIG 3D Cadastre Workshop, Athens, Greece, 18-20 October 2016.

98. Karabin, M.; Bakuła, K.; Fijałkowska, A.; Karabin-Zych, M. Feasibility study of 3D cadastre implementation using various data sources-the case of Warsaw Subway. Geod. Vestn. 2018, 62, 445-457. [CrossRef]

99. Jaworowska-Jurewicz, A. Prognoza Oddziaływania na Środowisko Miejscowego Planu Zagospodarowania Przestrzennego dla Dwutorowej Napowietrznej Linii Elektroenergetycznej 400 kV Ełk—Granica RP na Terenie Gminy Bakałarzewo Wynikająca ze Strategicznej Oceny Oddziaływania na Środowisko (in Polish) [Forecast of Environmental Impact of the Local Spatial Development Plan for the Double Track $400 \mathrm{kV}$ Ełk-Polish Border Overhead Power Line in the Bakałarzewo Commune Resulting from the Strategic Environmental Impact Assessment]. 2013. Available online: http://www.bakalarzewo.pl/asp/pliki/download/6.01.2013_ prog_bakalarzewo.pdf (accessed on 9 July 2019).

(C) 2019 by the authors. Licensee MDPI, Basel, Switzerland. This article is an open access article distributed under the terms and conditions of the Creative Commons Attribution (CC BY) license (http://creativecommons.org/licenses/by/4.0/). 